\title{
Comparison of crowding and food restriction effects on growth, body weight gain and endocrine status in the rat
}

\author{
C. Restrepo and A. Armario *
}

Departamento de biología celular y fisiología, Facultad de Ciencias, Universidad Autónoma de Barcelona, 08193 Bellaterra, Barcelona, Spain

(received 24 January 1989, accepted 16 May 1989)

Summary - The present work compares the effects of post-weaning crowding and those of food restriction on growth, body weight gain and the levels of several hormones, in male Sprague-Dawley rats. Crowding resulted in reduced food intake and diminished body weight gain. Rats daily receiving the same amount of food as that eaten by crowded rats (food-restricted group) showed similar body weight gain as crowded rats, but higher growth rate. Neither crowding nor food restriction altered the pituitary-adrenal axis. In contrast, both treatments decreased serum insulin, growth hormone (GH), somatomedin $\mathrm{C}(\mathrm{Sm}-\mathrm{C})$ and thyroid-stimulating hormone (TSH) as compared to control rats. The reduction of $\mathrm{GH}$ and $\mathrm{Sm}-\mathrm{C}$ levels was similar in crowded and food-restricted rats but that of TSH was higher in food-restricted, rather than in crowded rats. The present data indicate that the effects of crowding could only be partially explained by the concomittant reduction of food intake and that the serum levels of the hormones studied could not explain the differences between the crowded and food-restricted rats with regard to growth.

crowding - growth - corticosterone - insulin - growth hormone - somatomedin C thyroid stimulating hormone

Résumé - Comparaison des effets du surpeuplement et de la restriction alimentaire sur la croissance, le gain de poids corporel et le statut endocrinien chez le rat. Les effets du surpeuplement et de la restriction alimentaire après le sevrage, sur la croissance, le gain de poids corporel et les taux de plusieurs hormones ont été comparés chez les rats mâles Sprague-Dawley. Le surpeuplement entraîne une diminution de la consommation alimentaire et du gain de poids. Des rats recevant le même apport journalier d'aliments que celui consommé par les rats en surpeuplement (groupe à alimentation restreinte) ont des gains de poids similaires à ceux des rats en surpeuplement, mais des vitesses de croissance plus élevées. Ni le surpeuplement, ni la restriction alimentaire n'altèrent l'axe adréno-pituitaire. Par contre, les rats soumis aux traitements ont de plus faibles concentrations sériques d'insuline, d'hormone de croissance (GH), de somatomédine $C(\mathrm{Sm}-\mathrm{C})$ et de thyréostimuline (TSH), que celles des rats témoins. La diminution des taux de $\mathrm{GH}$ et de $\mathrm{Sm}-\mathrm{C}$ est similaire chez les rats en surpeuplement et chez ceux à alimentation restreinte, mais celle de TSH est plus forte dans le second lot. Les résultats montrent que les effets du surpeuplement ne peuvent être que partiellement expliqués par la réduction concomitante de la consommation d'aliment et que les taux sériques des hormones étudiées n'expliquent apparemment pas les différences entre surpeuplement et restriction alimentaire pour ce qui concerne la croissance.

surpeuplement - croissance - corticostérone - insuline - hormone de croissance somatomédine $c$ - thyréostimuline (TSH)

* Correspondence and reprints. 


\section{Introduction}

On the basis of laboratory and field studies (Christian et al., 1965; Gray, 1971), it was hypothesized that crowding might be a chronic stressful situation that would act as a feedback mechanism on the population to control its size by inhibiting reproductive processes and increasing mortality rate.

While this probably applies to overpopulation conditions in nature, it is not clear that this explanation could be relevant in more artificial conditions such as that obtained by increasing the number of animals per cage in the laboratory. Although earlier laboratory studies with mice support the hypothesis (Christian et al., 1965), the animals were isolated from weaning to the beginning of crowding and this manipulation probably increased aggressivity, thus potentiating the effects of crowding. In addition, isolated mice were used as controls without taking into account the possible influences of isolation (Brain, 1975). In an experiment with mice in which crowding was started immediately after weaning, neither adrenal hypertrophy, nor reduced testis weight were observed (Ortiz et al., 1984, 1985). With rats, crowding during adulthood did not increase either adrenal weight or basal serum corticosterone (Armario et al., 1984a, b; Armario and Lopez-Calderon, 1986).

Nevertheless, it appears that even under laboratory conditions, crowding can induce several abnormalities such as inhibition of food intake and body weight gain (Armario et al., 1984 a, b; Ortiz et al., 1985) and reduced serum levels of $\mathrm{GH}$ and TSH (Armario et al., 1987a). The reasons for the inhibition of food intake in crowded rats are not known, but it might be important to determine at least part of the alterations observed in crowded rats.
To date, no attempts have been made to differentiate between the physiological effects of partial food deprivation and those of crowding per se. To this end an additional group of animals were maintained at the same density of population as control rats and received the same amount of food as that eaten by crowded rats (food-restricted group).

\section{Materials and Methods}

Male Sprague-Dawley rats, $21-25$ days old, were used. They were maintained in a controlled environment (light cycle $07.00-$ $19.00 \mathrm{~h}$, temperature $22^{\circ} \mathrm{C}$ ). One bottle of water per cage, was always freely available. The animals were randomly assigned to 3 groups :

-32 control rats maintained in groups of 4 per cage $(48 \times 23 \times 14 \mathrm{~cm})$ with food ad libitum;

-60 crowed rats maintained in groups of 12 per cage (24 $\times 23 \times 14 \mathrm{~cm}$ ) with food ad libitum;

-32 food-restricted rats maintained in groups of 4 per cage $(48 \times 23 \times 14 \mathrm{~cm})$ but receiving the same amount of food as that eaten by crowded rats. On the first day, the amount of food given to pair-fed rats was based on a previous experiment. Afterwards, they received the same amount of food that was eaten by crowded rats the day before. To avoid changes in the circadian rhythms of some physiological variables, probably established by the time of food availability (Krieger, 1974; Krieger and Hauser, 1978; Honma et al., 1983), pair-fed rats were provided with food daily at $19.00 \mathrm{~h}$. Food intake was daily measured per cage and expressed as $\mathrm{g} / \mathrm{rat}$. Body weight was measured every $4 \mathrm{~d}$. Anal-naso length was measured, under slight ether anesthesia, at the beginning, and $6 \mathrm{~d}$ before the end of the experiment which lasted $30 \mathrm{~d}$. The last day, several rats from each experimental group were quickly killed by decapitation the day that followed the last food presentation to pair-fed rats, i.e. between 09.00 and $11.00 \mathrm{~h}$. Immediately after decapitation, the two adrenal glands were removed, trimmed of fat and weighed. The trunk blood was collected in plastic tubes maintained at $4{ }^{\circ} \mathrm{C}$ and 
centrifuged $1 \mathrm{~h}$ later at the same temperature. The serum was frozen at $-20^{\circ} \mathrm{C}$ until analysis. All hormones were analysed by radioimmunoanalysis. Corticosterone was determined as described by Armario et al. (1984a); insulin was measured with a commercial kit (Amersham) using rat insulin (Novo Res. Inst.) as standards. Growth hormone $(\mathrm{GH})$ and Thyroid stimulating hormone (TSH) were determined by double antibody radioimmunoassays using reagents kindly provided by the NIDDK through the National Hormone and Pituitary Program (Baltimore, Maryland, USA). The values were expressed in terms of the GH-RP-1 and TSH-RP-1 standards. Somatomedin C $(\mathrm{Sm}-\mathrm{C})$ was measured without extraction with a commercial kit (Nichols) developed for human $\mathrm{Sm}-\mathrm{C}$ assay. A good parallelism was observed between the standard curve and several rat serum dilutions. Values were expressed in terms of human standards; however the rat standard was 21.6 times more potent than the human standard (L.E. Underwood, personal communication). Serum glucose was determined by the glucose oxidase method (Farmitalia Carlo Erba). All the samples to be statistically compared were processed within the same assay to avoid interassay variations. Intra-assay coefficients of variation were always below $10 \%$.

The statistical significiance of the results was evaluated with ANOVA. Post-hoc individual comparisons were carried out with the Duncan multiple range test $(\alpha=0.05)$.

\section{Results}

Both food restriction and crowding significantly inhibited body weight gain as compared with control rats; the inhibition being similar in food-restricted and crowded rats (Fig. 1). As Table I shows, the inhibition of growth, as measured by anal-naso length, was greater in crowded than in food-restricted rats. The discrepancies between the results obtained by measuring body weight, and those measuring growth, can be explained by the greater fat accumulation of crowded, as compared to food-restricted, rats. This difference was visually expressed in the whole body and was quantified by measuring the epididymal fat pad, which was greater in crowed than in foodrestricted rats. Neither crowding, nor food restriction, significantly altered adrenal weight or serum corticosterone levels.

Table II depicts serum glucose, insulin and TSH levels. Insulin concentrations were low in crowded and food-restricted rats, with no significant differences between the 2 groups. Serum glucose

Table I. Effects of crowding and food restriction on some physiological variables in male rats.

\begin{tabular}{|c|c|c|c|c|c|}
\hline Group & $\begin{array}{l}\text { Incremental } \\
\text { change in } \\
\text { anal-naso length a }(\mathrm{cm})\end{array}$ & $\begin{array}{l}\text { Food intake b } \\
\text { (g/rat/day) }\end{array}$ & $\begin{array}{l}\text { Epididymal fat a } \\
\operatorname{pad}(g)\end{array}$ & $\begin{array}{l}\text { Adrenal weight a } \\
(m g / 100 \mathrm{~g} \mathrm{bw})\end{array}$ & $\begin{array}{l}\text { Serum } \\
\text { corticosteronea } \\
(\mu g / d l)\end{array}$ \\
\hline Control & $\begin{array}{l}7.0 \pm 0.3 \\
(8)\end{array}$ & $\begin{array}{l}20.0 \pm 0.4 \\
(8)\end{array}$ & $\begin{array}{l}1.2 \pm 0.1 \\
(6)\end{array}$ & $\begin{array}{l}15.0 \pm 1.0 \\
(6)\end{array}$ & $\begin{array}{l}0.59 \pm 0.13 \\
(6)\end{array}$ \\
\hline Crowding & $\begin{array}{l}5.3 \pm 0.3^{* *} \\
(8)\end{array}$ & $\begin{array}{l}14.8 \pm 0.2^{\star \star} \\
(8)\end{array}$ & $\begin{array}{l}0.7 \pm 0.1 \text { ** } \\
(6)\end{array}$ & $\begin{array}{l}17.2 \pm 0.4 \\
(6)\end{array}$ & $\begin{array}{l}2.04 \pm 0.82 \\
(6)\end{array}$ \\
\hline $\begin{array}{l}\text { Food } \\
\text { restriction }\end{array}$ & $\begin{array}{l}6.4 \pm 0.2^{*} \\
(8)\end{array}$ & - & $\begin{array}{l}0.4 \pm 0.1^{\star \star}, \star \\
(6)\end{array}$ & $\begin{array}{l}18.0 \pm 1.3 \\
(6)\end{array}$ & $\begin{array}{l}0.71 \pm 0.44 \\
(6)\end{array}$ \\
\hline
\end{tabular}

Means \pm SEM are indicated. $N$ values are in parentheses. a number of animals per group and, $b$ number of cages controlled. ${ }^{* *} P<0.05$ vs controls. ${ }^{*} P<0.05$ vs crowded rats. 
Table II. Effect of crowding and food restriction on serum insulin, glucose and TSH levels in male rats.

\begin{tabular}{llll}
\hline & $\begin{array}{l}\text { Insulin } \\
(\mathrm{mU} / \mathrm{ml})\end{array}$ & $\begin{array}{l}\text { Glucose } \\
(\mathrm{mg} / \mathrm{d})\end{array}$ & $\begin{array}{l}\mathrm{TSH} \\
(\mathrm{ng} / \mathrm{ml})\end{array}$ \\
\hline Control (5) & $59.3 \pm 10.9$ & $155.7 \pm 3.9$ & $530 \pm 21$ \\
Crowding (6) & $29.8 \pm 4.3^{*}$ & $143.9 \pm 1.3^{*}$ & $271 \pm 31^{*}$ \\
Food (6) & $28.0 \pm 4.3^{*}$ & $149.4 \pm 2.6$ & $170 \pm 18^{*, * *}$ \\
\hline
\end{tabular}

Mean \pm SEM are represented. The number of animals per group is given in parentheses. $P<0.05$ vs controls, ** $P<0.05$ vs crowded rats (Duncan test).

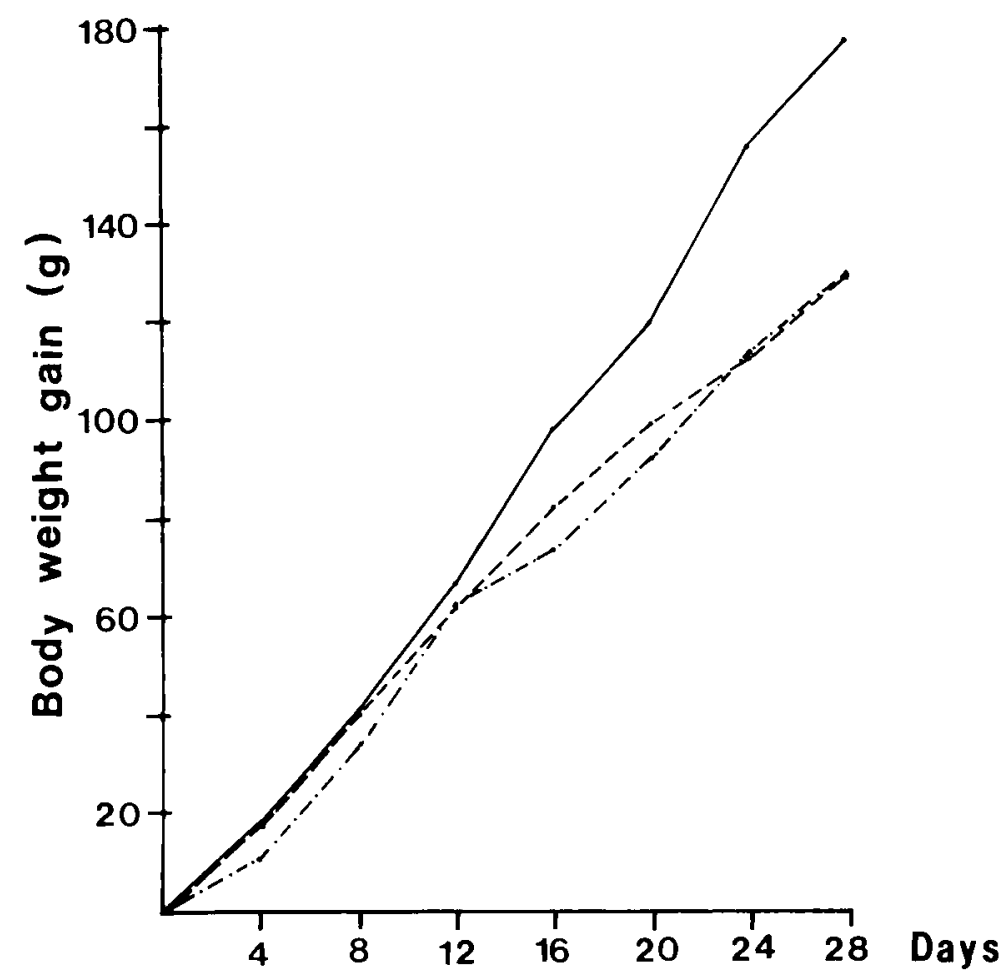

Fig. 1. Body weight gain in control (-), crowded (----) and food-restricted (--.---) rats $(N=8)$. The latter rats received the same amount of food as that eaten by crowded rats. The differences between crowded and food-restricted rats were not significant. The 2 groups showed significantly lower body weight gain, than the control rats. 
was significantly lower in crowded, than in control rats; the levels of food-restricted rats being intermediate between those of the other 2 groups. Both crowded, and food-restricted rats, showed significantly reduced $\mathrm{TSH}$ levels, but the reduction was greater in the latter animals.

Crowding and food restriction treatments resulted in reduced serum $\mathrm{GH}$ and $\mathrm{Sm}-\mathrm{C}$ levels (Fig. 2). No significant differences between crowded and foodrestricted rats were found.

\section{Discussion}

As expected from previous results (Amir et al., 1979; Armario et al., 1984a, b; Armario and Lopez-Calderon, 1986; Ortiz et al., 1985), crowding reduced food intake in spite of free and continuous availability of the pellets. Although the ultimate reason for the inhibition of food intake observed in crowded rats is not known, it was apparently not due to lack of space at the feeder or to difficult access to the water bottle, since an increase of space at the feeder or in the number of bottles of water does not enhance water and food intake in crowded rats (unpublished data). The present results indicate that a dissociation might exist between growth and body weight in crowded and food-restricted rats. This dissociation could be explained by the greater fat accumulation in crowded, as compared to food-restricted, rats. This accumulation of fat might be the consequence of the inhibition of growth which, in turn, would delay the age at which the animals reached sexual maturity.

The physiological basis for differential growth are unknown and no explanation, in terms of the serum concentration of various hormones related to growth (see below) was apparent.

The lack of effect of crowding on basal pituitary-adrenal function has been repeatedly observed in our laboratory (Armario et al., 1984a, b; Ortiz et al., 1985), suggesting that, under our conditions, crowding could not be considered as a classical stressor. Crowded and foodrestricted rats showed similar glucose and

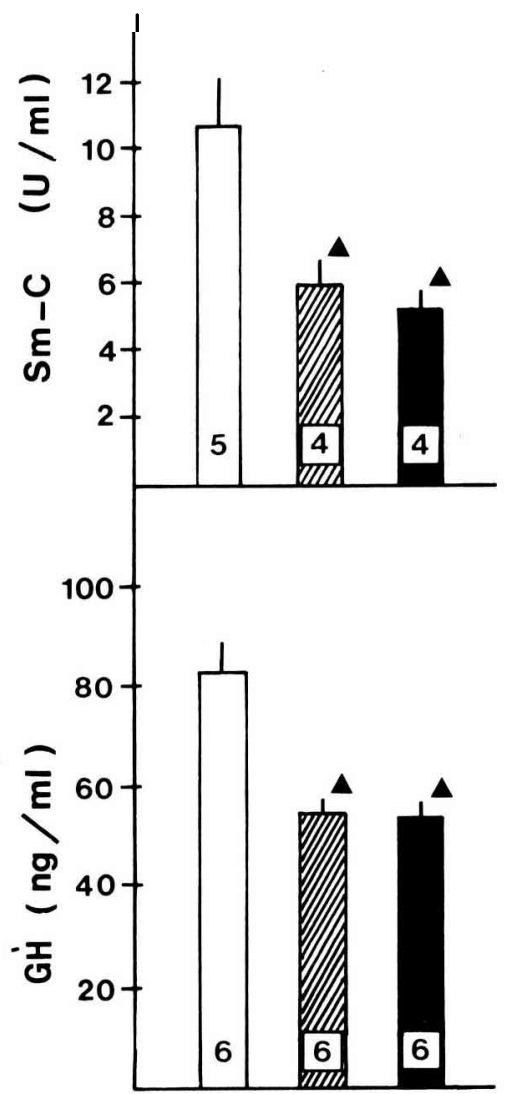

Fig. 2. Effects of crowding and food-restriction on serum $\mathrm{GH}$ and Sm-C levels. Mean \pm SEM are represented. The number of rats per group is within the bars. Open bars indicate controls, hatched bars, crowded rats, and closed bars, food-restricted animals. $\Delta P<0.05$ vs control rats (Duncan test). 
insulin levels, which suggests that inhibition of insulin secretion in crowded rats might be entirely explained by the reduction of food intake (Armario et al., 1983; Becker, 1983). However, serum glucose was significantly reduced in crowded, but not in food-restricted rats. Since crowded rats apparently had higher fat content than food-restricted rats, it seems possible that crowding induced some abnormalities in fat mobilization, thereby increasing glucose utilization.

Crowding and food restriction significantly reduced serum $\mathrm{GH}$ and $\mathrm{TSH}$ levels. This is consistent with previous findings (Armario et al., 1987a), and with the fact that, in the rat, chronic proteincalorie undernutrition inhibits the secretion of these 3 hormones (Armario et al., 1987b; Doorn et al., 1984; Ortiz-Caro et al., 1984). While serum GH levels were similar in crowded and food-restricted rats, serum TSH levels were higher in crowded, than in food-restricted rats. The physiological meaning of the differences in TSH secretion between crowded and food-restricted rats, especially with regard to differential body weight gain, remains to be established.

Crowding and food restriction resulted in low, but similar levels, of $\mathrm{Sm}-\mathrm{C}$. Although direct measurement of $\mathrm{Sm}-\mathrm{C}$ in serum might result in underestimated values due to the presence of binding proteins, the good parallelism observed with several serum dilutions suggests that qualitative interpretation of the present results is probably correct. Despite the significant reduction of $\mathrm{GH}$ and $\mathrm{Sm}-\mathrm{C}$ levels in food-restricted rats, the increment of anal-naso length was similar in food-restricted and control rats. This suggests that : the impaired $\mathrm{Sm}-\mathrm{C}$ secretion observed in food-restricted rats was not sufficient to alter growth; and the growth inhibition caused by crowding was not a direct consequence of reduced food intake.

in conclusion, the present data offer clear evidence that some of the physiological abnormalities, induced by crowding, were not merely a consequence of either reduced food intake or increased adrenocortical activity. In addition, crowded rats showed impaired growth as compared with food-restricted rats. However, basal serum levels of the hormones studied (corticosterone, insulin, $\mathrm{GH}, \mathrm{Sm}-\mathrm{C}$ and TSH), cannot easily explain the differences between crowded and food-restricted rats.

\section{Acknowledgements}

Thanks are given to $\mathrm{Dr}$. T. Jolin for the $\mathrm{GH}$ and TSH assays.

\section{References}

Amir S., Galina H.Z. \& Amit Z. (1979) Chronic naltrexone administration reverses the suppressive effect of crowding on body weight change in rats. Neuropharmacology 18, 905-907

Armario A., Castellanos J.M. \& Balasch J. (1983) Chronic noise and water restriction as stress models in relation to food and water intake and hormonal profiles in adult male rats. Nutr. Rep. Int. 28, 1333-1339

Armario A., Castellanos J.M. \& Balasch J. (1984a) Effect of crowding on emotional reactivity in male rats. Neuroendocrinology 39, 330-333

Armario A., Garcia-Marquez C. \& Jolin T. (1987a) Crowding-induced changes in basal and stress levels of thyrotropin and somatotropin in male rats. Behav. Neural Biol. 48, 334343

Armario A. \& Lopez-Calderon A. (1986) Pituitary-gonadal function in adult male rats 
subjected to crowding. Endocrine Res. 12, 115122

Armario A., Montero J.L. \& Jolin T. (1987b) Chronic food restriction and the circadian rhythms of pituitary-adrenal hormones, growth hormone and thyroid-stimulating hormone. Ann. Nutr. Metab. 31, 81-87

Armario A., Ortiz R. \& Balash J. (1984b) Effect of crowding on some physiological and behavioral variables in adult male rats. Physiol. \& Behav. 32, 35-37

Becker D.J. (1983) The endocrine response to protein calorie malnutrition. Ann. Rev. Nutr. 3, 187-212

Brain P.F. (1975) What does individual housing mean to a mouse? Life Sci. 16, 187-200

Christian J.J., Lloyd J.A. \& Davis D.E. (1965) The role of endocrines in the self-regulation of mammalian populations. Recent Prog. Horm. Res. 21, 501-578

Gray J.A. (1971) The Psychology of Fear and Sress. Weidenfeld and Nicolson, London

Honma K.I., Von Goetz C. \& Aschoff J. (1983) Effects of restricted daily feeding on freerunning circadian rhythms in rats. Physiol. Behav. 30, 905-914
Krieger D.T. (1974) Food and water restriction shifts corticosterone, temperature, activity and brain amine periodicity. Endocrinology 95, 1195-1201

Krieger D.T., Hauser H. (1978) Comparison fo synchronization of circadian corticosteroid rhythms by photoperiod and food. Proc. Natl. Acad. Sci. USA 75, 1577-1581

Ortiz R., Armario A., Castellanos J.M. \& Balasch J. (1985) Post-weaning crowding induces corticoadrenal hyperreactivity in male mice. Physiol. \& Behav. 34, 857-860

Ortiz R., Castellanos J.M. \& Armario A. (1984) Post-weaning differential housing and testosterone secretion in male mice. Experientia 40, 1428-1429

Ortiz-Caso J., Gonzalez C. \& Jolin T. (1984) Diurnal variations of plasma growth hormone, thyrotropin, thyroxine, and triiodothyronine in streptorotocin-diabetic and food restricted rats. Endocrinology 115, 2227-2232

Van Doorn J., Van Der Heide D. \& Roelfsema F. (1984) The influence of partial food deprivation on the quantity and source of triiodothyronine in several tissues of athyreotic thyroxine-maintained rats. Endocrinology 115, 705-711 